\title{
The Rubber Industry of Indonesia: Strategy for Competitiveness and Sustainability
}

\author{
Musdhalifah Machmud ${ }^{1,2 *}$ Hermanto Siregar ${ }^{3}$ Harianto $^{4}$ Wayan Reda Susila ${ }^{5}$ \\ 1. Doctoral Programme of Business School, IPB University, PO box 16128, Bogor, Indonesia \\ 2. Deputy Ministry for Food and Agribusiness, Coordinating Ministry for Economic Affairs Republic of \\ Indonesia, PO box 10710, Jakarta, Indonesia \\ 3. Department of Economics, IPB University, PO box 16880, Bogor, Indonesia \\ 4. Department of Agribusiness, IPB University, PO box 16880, Bogor, Indonesia \\ 5. School of Business and Economics, Prasetiya Mulya University, PO box 15339, BSD-City, Indonesia \\ *E-mail of the corresponding author: musdhalifahmachmud@gmail.com
}

\begin{abstract}
The paper presents a systematic review of the latest developments in the natural rubber industry and describes the major predictors for the sustainability of Indonesia's competitive advantage in this sector. In-depth interviews with experts were conducted to gather data from the private and public industries, International Trade Statistic, and Statistics Indonesia. The data were analyzed using the Diamond Model, which is widely used as the framework of a country's competitive advantage. The data is processed to find the RCA value and mapping the factors affecting the competitive advantages of ITRC countries. In the face of falling rubber prices, the Indonesia rubber industry's recent management strategy is to increase competitiveness sustainably by increasing productivity in the upstream industry and efficiency in the downstream industry. To boost competitiveness even further, a more concentrated endeavor to stimulate innovation and technology adoption by farmers and businesses is required. The study offers a comprehensive examination of Indonesia as a country with major agricultural export industries. It methodically investigates the strategies that must be implemented to sustain the rubber industry in Indonesia.
\end{abstract}

Keywords: competitiveness, industry, natural rubber, revealed competitive advantage, sustainability

DOI: $10.7176 / \mathrm{EJBM} / 14-3-06$

Publication date: February $28^{\text {th }} 2022$

\section{Introduction}

Indonesia is a rising market economy, having exports amounted to $20.37 \%$ of GDP (BPS 2018). Rubber has consistently been among the Indonesia's best ten export commodities, and it is now the country's most important agricultural export. The rubber industry (in Figure 1) employs over three million people (BPS 2013). As rubber tapping can be carried out throughout the year, rubber plantations can provide employment in agriculture.

Malaysia led the world's rubber export before 1990, followed by Indonesia as the second and Thailand as the third-largest exporter (in Figure 2). Since 1991, however, Thailand has taken the place of Malaysia as the world's exporter of rubber. The declining rubber industry in Malaysia was due to labor migration to other industries and the expansion of other profit crops, for example, cocoa and oil palm (Booranapin 2000). Meanwhile, Indonesia has opportunities to grow its export along with the increased trade liberalization. Also, free trade agreements (FTAs) will enable additional opportunities for expansion into new markets for rubber companies (in Figure 3).

With this background, the present study seeks to investigate the current state of Indonesia's rubber industry and better comprehend Indonesia's strategy in an increasingly competitive global market and in the face of the sustainability issue. Following a review of fundamental definitions and related concepts, the generic cluster industry model and Porter Diamond Model are introduced. Furthermore, the analytical framework is implemented in the Indonesia's rubber industry. In our conclusion, we suggest existing strengths and weaknesses, followed by forthcoming opportunities and threats, based on the analysis. 


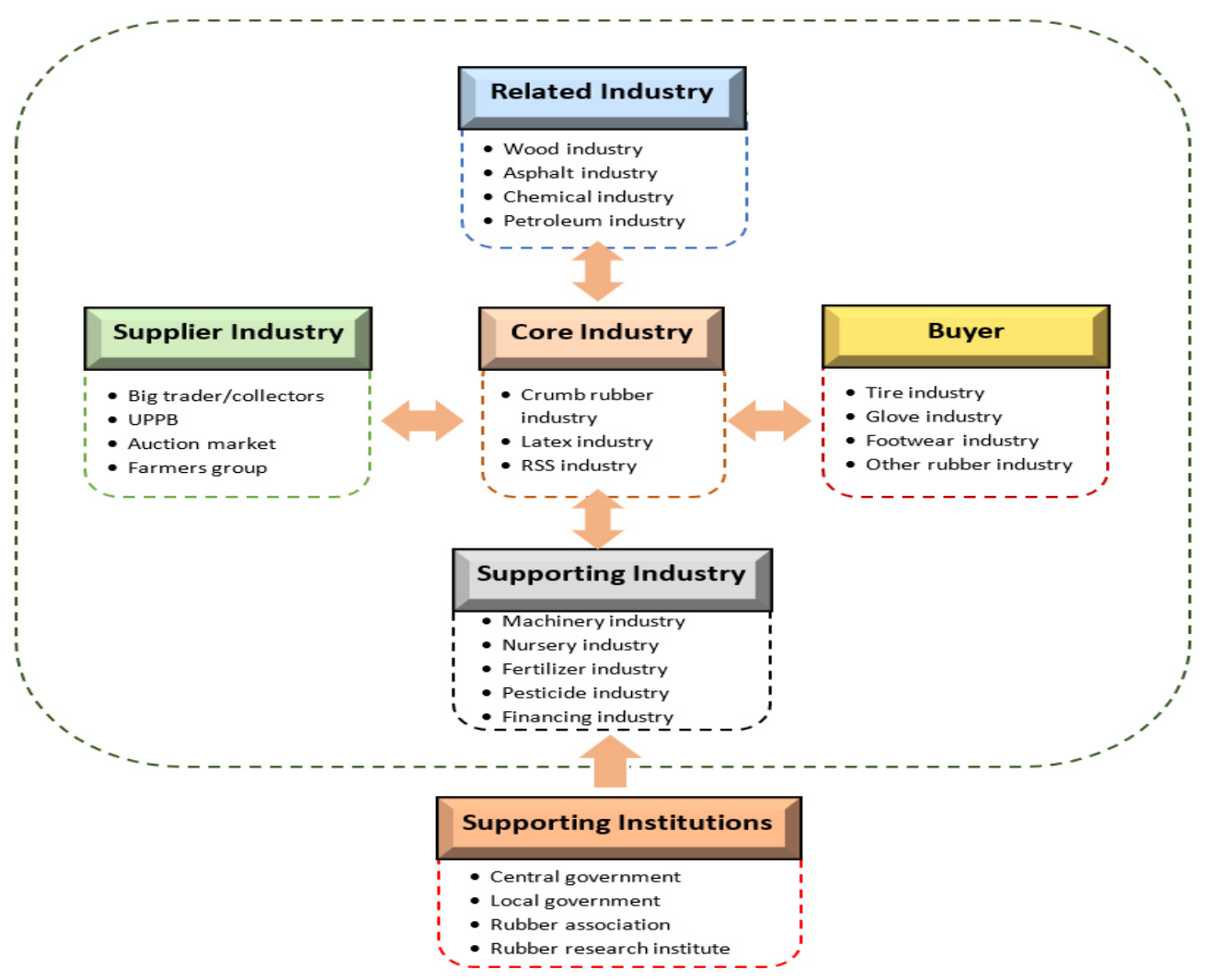

Figure 1. Rubber Industry Cluster Model (modified from Porter, 1990)

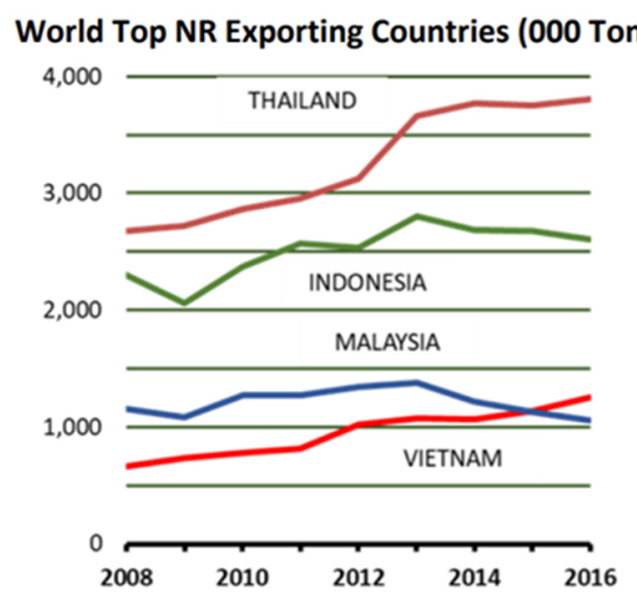

Figure 2. The Largest Natural Rubber Exporting Countries 


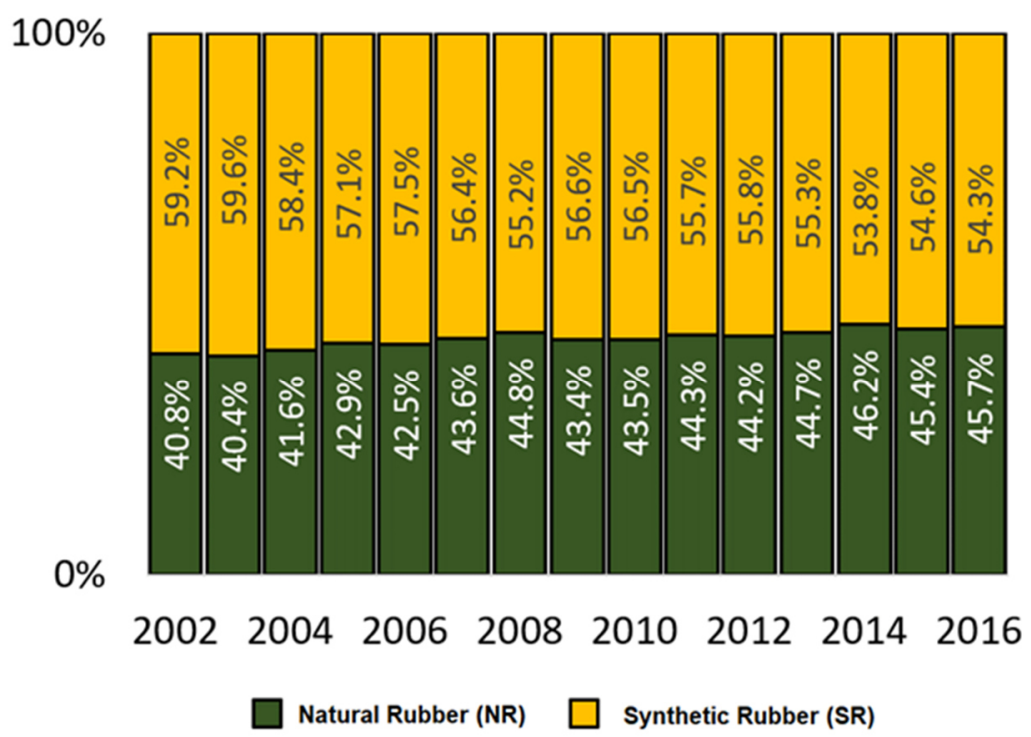

Figure 3. The Proportion of World Rubber (NR and SR) Consumption 2002-2016

\section{Materials and Methods}

\subsection{Data Collection and Methods}

This section explains the data collection and analytical procedures used in the study. We conducted in-depth interviews with general managers of rubber export companies, the Head of the Indonesian Rubber Association, and officials in related government agencies to yield primary data. Secondary data (rubber export from Indonesia) were gathered from the International Trade Statistic website 2019. Then, the data was processed using the RCA formula. The explanations of the interview in detail are provided hereunder.

The initial in-depth interview was carried out with a general manager of PT Kirana Megatara, the largest producer of crumb rubber in Indonesia, with an $18 \%$ share of Indonesia's total exports. The corporation was established in 1964 and went public in 2017. It presently has 14 manufacturing plants in various regions of Indonesia and a branch office in Jakarta, Indonesia. To date, the Kirana Megatara group consists of 14 factories that produce crumb rubber, including SIR-10, SIR-20, and SIR 20 VK types. It is the largest crumb rubber exporter in Indonesia, which produces 720,000 tons annually. The majority of the company's products are sold overseas to the global tire manufacturers, including Bridgestone, Michelin, Cooper Tires, Goodyear, Continental, Sumitomo, Pirelli, Hankook Fate, Yokohama Rubber, Apollo Tyers, Kumho Tyres, Nexen, Toyo Tires, and Gajah Tunggal.

A second interview was conducted with the head of the farmer group PT Djambi Waras. Founded in 2008, the farmer group supply raw rubber materials to PT Djambi Waras. Farmers receive better prices as an incentive to produce quality rubber, keep the quality of rubber clean, and keep the rubber from being mixed with materials that could lower the price of rubber farmers.

The companies selected for interviews, besides large and proficient exporters, are also public companies listed on the Indonesia Stock Exchange. This allows us to verify the information about the company's operations.

We also had an interview session with department heads from the Jambi Bureau of Statistic in order to obtain data on the state of rubber in Jambi province as the fourth largest rubber production in Indonesia and the third crumb rubber producer in Indonesia. The vast majority (92-95\%) of rubber plantations in Jambi are owned by smallholders.

The five interviews provided the researchers with perspectives and ideas from a diverse group of concerned parties in the industry, including a big exporter, farmers' group, PT Djambi Waras, Rubber Association of Indonesia, Indonesian Rubber Research Institute, Rubber Expert from Jambi University, and government offices in charge of the rubber industry. When viable, information gleaned from interviews was verified with official publications obtained from various sources, including the Rubber Association of Indonesia, the Ministry of Trade, the Bureau of Statistic, and the International Rubber Study Group.

The information gathered was gone through the process of reviewing and com-paring for recurring themes and similarities. This study classified the major strengths and weaknesses of Indonesia's rubber industry using the Diamond Model. From the standpoint of our interviewees, significant future opportunities and threats were identified and documented. Prior to finalization, the qualitative analysis included a thorough examination of the research team as well as repeated consultations with industry experts from the public sector and private sector. 


\subsection{Revealed Comparative Advantage (RCA) Analysis}

The analytical procedure involves the analysis of RCA, which refers to a ratio of export value of a certain commodity from a certain country to total export value from all producing countries. This index indicates the changes in comparative advantage or competitiveness of the country in the international market (Tambunan 2001). RCA formula is as follows (in Equation 1):

$$
R C A=\frac{X_{i k / X_{i}}}{W_{i k} / W_{i}}
$$

Description:

Xik : the value of rubber commodity export from Indonesia

$\mathrm{Xi} \quad$ : total export value (rubber and other products) from Indonesia

Wik : the value of rubber commodity exports in the world

Wi : total world export value

The value of RCA greater than 1 implies that Indonesian rubber has a higher comparative advantage than other rubber producers in the world (in Figure 4). Otherwise, it means that the comparative advantage of Indonesian rubber is poor, under the global competitiveness.

\section{Results}

\subsection{Rubber Industry Competitiveness and Sustainability}

Rubber is made from two different sources. The first source is natural rubber which is cropped from the Para rubber tree, a species indigenous to the Amazon Rainforest. Besides Indonesia, it is also primarily grown commercially in Malaysia and Thailand. The second source, synthetic rubber is created from petrochemicals. This type of rubber is largely produced and consumed in the USA, China, and Russia (in Figure 5). The following discussion of the rubber industry in this study is mainly laid on natural rubber.

There are two industries revolving around natural rubber production: upstream and downstream. The term "upstream industry" refers to the process of converting the outputs from rubber plantations, mostly smallholders, into concentrated latex or coagulated rubber. Coagulated rubber is subcategorized into two: rubber sheets or ribbed smoked sheets (RSS) and blocks or technically specified rubber (TSR). Traditionally, TSR has been sold at a lower price than RSS, however, it has lately seen greater demand owing to the resemblance of TSR block sizes to synthetic rubber, which simplifies the increased and mixed processes in tire production (DBS 2011).

The downstream industry denotes the rubber products manufacturing industry, which primarily stocks inputs for automotive (e.g., tires, moldings, belts, gaskets, hoses), industries (e.g., adhesives, padding, belting, wire sheathing, vibration dampening,), construction (e.g., sealants, moldings, roofing), as well as consumer goods (e.g., toys, door moldings) (Ita and Gross 1995).
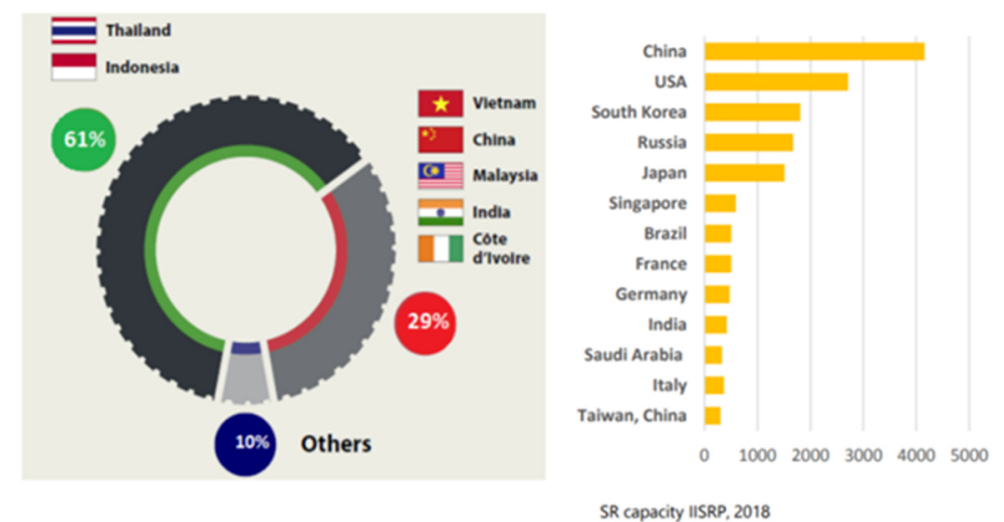

Figure 4. Rubber Supply-Major Countries 


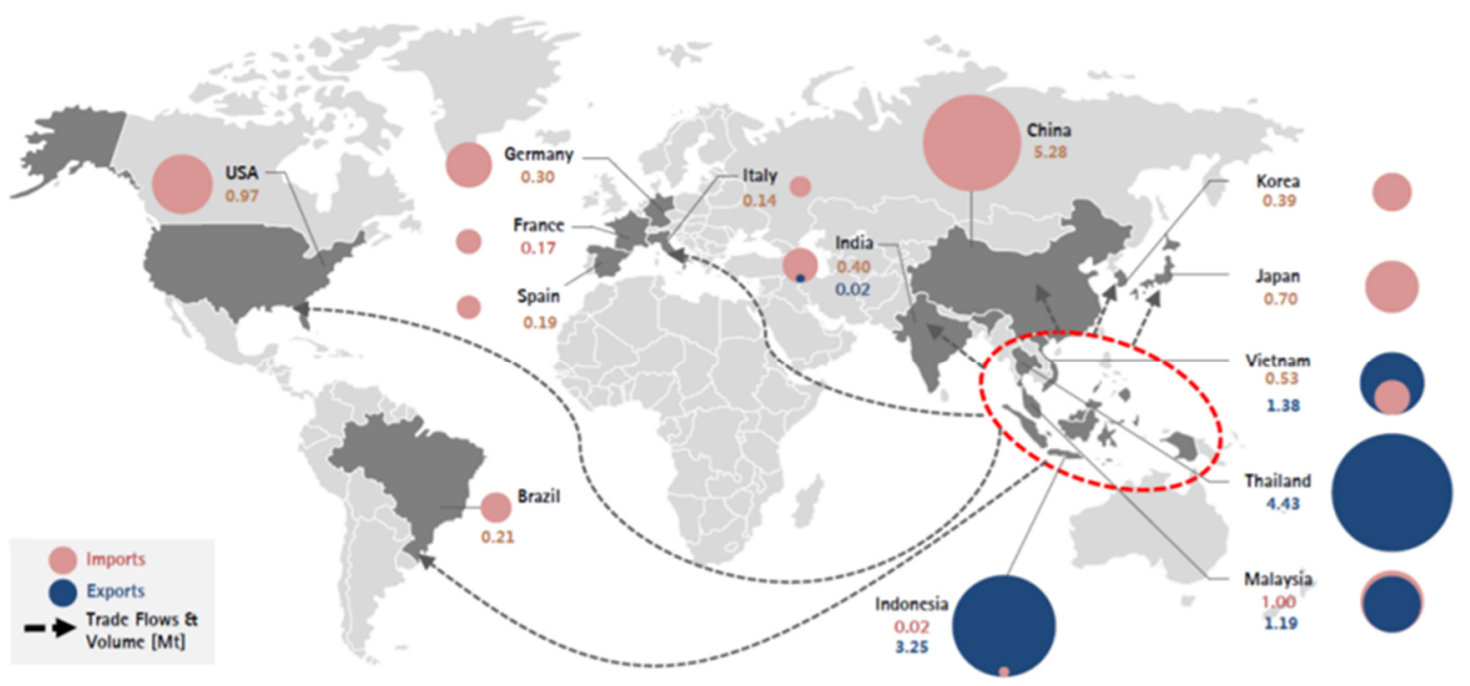

Figure 5. Major Driver for Natural Rubber Consumption and Trade is China The global market. On the global market, rubber trade is done through two ways, as follows:

(1) Open market: it is a 24-hour market operating in a designated sequence, starting from Tokyo Market, Shanghai Market, Singapore Market (in Figure 6), London Market, and lastly, New York Market. Due to its transparency, price quotes, as well as order, can be made without difficulty in this market.

(2) Direct trade: it is a type of business involving a direct transaction between customers and manufacturers. Typically, manufacturers do not disclose the price (Min et al. 2018). The majority of the buyers are large tier manufacturers such as Bridgestone, Michelin, Pirelli, Continental, and Goodyear. At present, as many as $80 \%$ of global rubber trading is comprised of direct trade.

The global rubber production of both natural rubber and synthetic rubber is presently around 28 million tons (IRSG 2019), almost half (48\%) of which is natural rubber. Because the oil price is on the rise, the proportion of natural rubber has increased over the last decade.

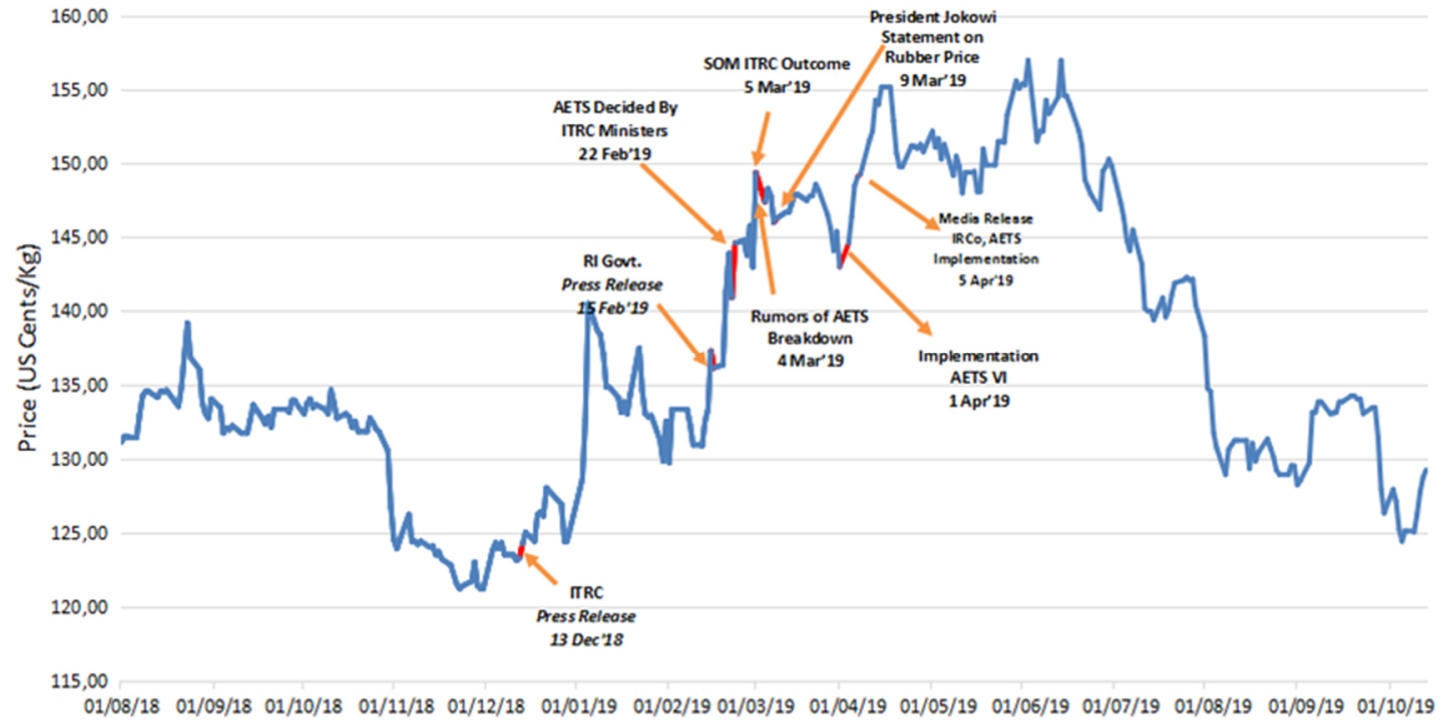

Figure 6. Sicom TSR 20 Rubber Price August 2018- October 2019

Between 2000 and 2018, the annual growth rate of natural rubber output on average was around $3 \%$. The biggest producers were Thailand (35.5\%), followed by Indonesia (25.5\%) and Vietnam (8.1\%). Only Thailand and Indonesia, among the top three, have the prospective to boost output by broadening plantations to new areas.

Over the same period, natural rubber consumption worldwide has grown at a moderately lower rate (annual rate of $2.8 \%)$. China $(39.9 \%)$, India $(8.2 \%)$, and the United States $(7.4 \%)$ were the top three rubber-consuming countries in 2017.

Figure 6 depicts the natural rubber price trend (Technically specified rubber 20/ TSR 20), one of Indonesia's 
greatest categories of main rubber exports found in the Singapore market (Singapore Commodity Exchange/SICOM). Apparently, prices have been consistently decreasing since early 2011. Beginning in 2014, the economic slowdown worldwide drove a considerable falling price. On the other hand, prices have significantly recovered, reaching a new high in 2011.

The definition of sustainability is sustaining the asset value of a product without compromising the asset value of nature and society so that future generations can continue to benefit from the sustained asset. SDGs 2030 have 17 goals, 169 targets, and 240 indicators. There are 12 principles of sustainability that can be initiated in Rubber Plantation: forest sustainability, land rights, water management, labor rights, human rights, traceability, equity, grievance mechanism, transparent reporting, anti-corruption, auditing protocols, training and education.

\subsection{Competitiveness and Competitive Advantage}

The World Economic Forum (2019) describes competitiveness as a collection of institutions, policies and factors that influence productivity levels (in Figure 7). Competitiveness can be seen from three insights at a macroeconomic level: productivity, capacity to create welfare, and ability to sell in external markets. Ketels (2016) divides the definition of competitiveness into two views, namely, the cost-/market share view and the productivitybased view. Aiginger (2013) gives a new perspective on competitiveness outcome, which integrates income, social, and ecological pillar. Another conception of competitiveness, according to the OECD (2001), is "a measure of a country's advantage or disadvantage in selling its products in international markets." Strategic management revolves around the concept of competitive advantage. The concept relates to outperforming the average rival companies in the same industry in terms of profitability (Besanko et al. 2010). The Diamond Model (Porter 1990) represents a framework for identifying the determinants of a country's competitive advantage. In this model, the crucial issue is, "Why are firms based in a specific country able to create and sustain a competitive advantage against the world's best competitors in a specific industry or segment?" The explanation lies on four extensive characteristics of a country that shape the environment where the local firms race and either help or impede competitive advantage. Each factor listed below specifies a point on the national advantage diamond.

(1) The first point is factor conditions, reflecting the country's position in terms of production factors consisting of land, labor, and capital. The Porter Diamond Model of National Advantage surpasses traditional classical theory factors by focusing on generated factors (e.g., skilled labor, infrastructure) needed to remain competitive in a particular industry. Firms competing in other environments will find it difficult to replicate all of these factors.

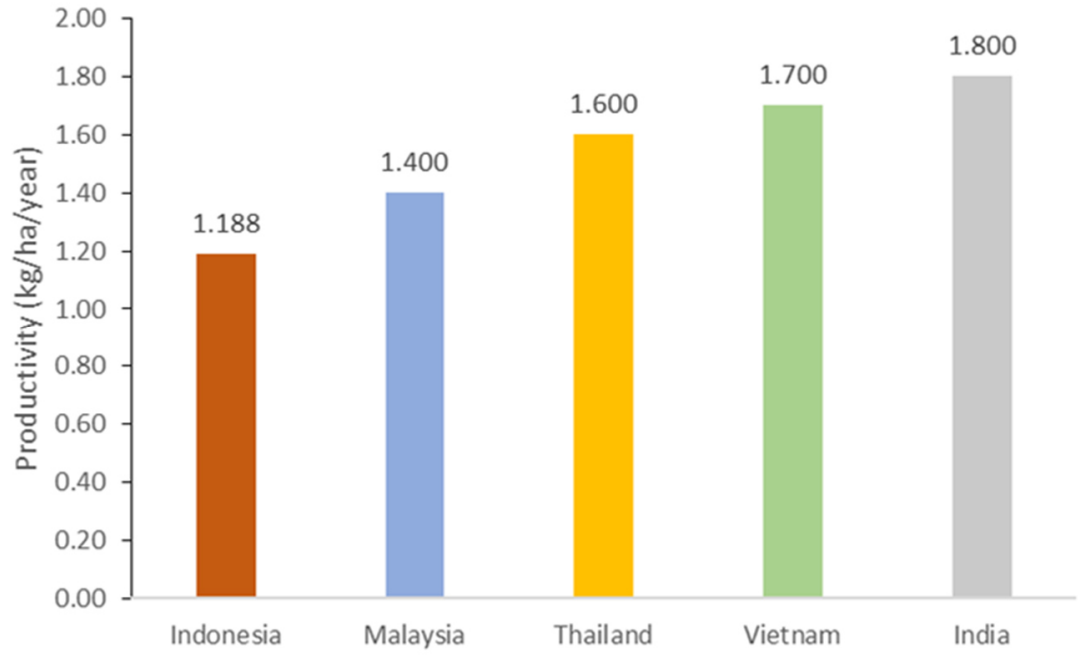

Figure 7. Productivity of Rubber Plantations in Several Natural Rubber Producing Countries in The

World

(2) The second point is demand conditions, referring to the character of the product or service's domestic demand in the industry. Firms can more conveniently reach a minimum efficient scale in a large domestic market. Local consumers, those who are characterized as experienced and demanding, lead the industry towards growth and maintenance of a worthwhile competitive advantage.

(3) The third point is related and supporting industries that denote the existence of domestic suppliers and other associated industries that are internationally competitive. Local suppliers might assist in reducing costs of production. Local firms' competitiveness in related industries can as well provide significant advantages such as ample flow of information and technical interchange.

(4) The fourth point is firm strategy, structure, and rivalry, denoting the national conditions that govern the company's formation, organization, and management, along with the nature of the domestic competitiveness. 
A sustained competing constraint from powerful domestic opponents is critical in driving companies to boost productivity and innovation continuously.

In addition to the four previously mentioned factors, Porter (1990) recognizes the fifth major influence, that is, "Government Policy." The government's fitting role is to serve as an accelerator and contender to stimulate companies to better their performances. Also, rather than directly intervening in the business process, the government is expected to promote the formation of an environment that enables companies to acquire a competitive edge.

Finally, the impact of global activity is becoming more prominent in the assessment of national competitiveness (Moon et al. 1995). Thus, it is critical to consider the role of multinational corporations and foreign direct investment in building and reinforcing factors of production, demand conditions, related and supporting industries, as well as firm strategy, structure and rivalry. The Porter Diamond Model is employed to shed light on several crucial aspects that contribute to the competitiveness and sustainability of Indonesia's rubber industry.

\section{Discussion}

We present the study's findings in accordance with the Diamond Model structure developed by Porter (1990). The components comprise factor conditions; demand conditions; related and supporting industries; firm strategy, structure, and rivalry; and policy intervention by the government.

\subsection{Factor Conditions}

Indonesia's tropical climate is very appropriate for rubber plantations. The country currently has 3.7 million hectares of rubber plantation, making it the world's biggest rubber plantation area (in Figure 8). The government has declared schemes to replant plantations by approximately 50,000 hectares per year (Sinar Tani 2019).

Overall, Indonesia's infrastructure is up to par in the $72^{\text {nd }}$ position from 141 countries in the 2019 Global Competitiveness Index (GCI) (WEF 2019). It now has a workforce of more than 131 million people, the vast majority of whom are under 39. About 2.29 million people participate each year (Sinar Tani 2019). The minimum wage in Indonesia is Rp 80,000 per day, rather lower in the provinces in which the cost of labor is significantly lower than the neighboring countries excluding Cambodia. The government has declared the salary system policy, which ensures annual salary increase for laborers at a measured rate. The policy will provide certainty for entrepreneurs to doing business.
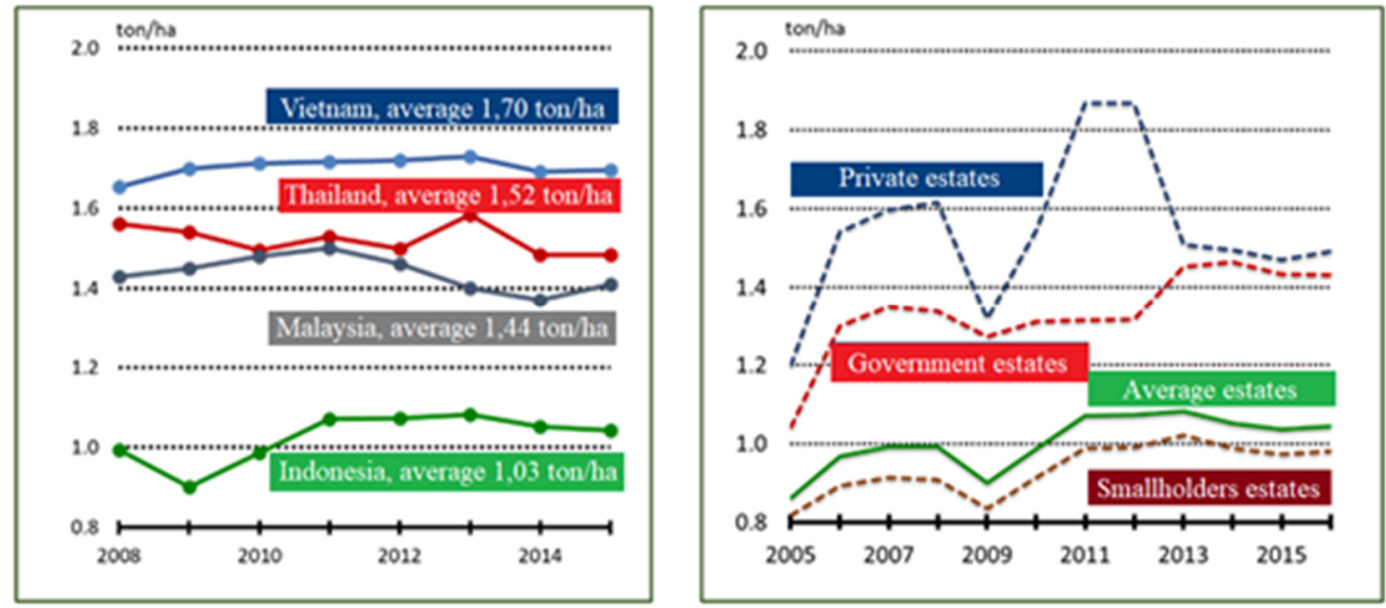

Figure 8. Annual Productivity of Natural Rubber

Smallholders control the majority of rubber plantations in Indonesia. Rubber tapping is a challenging job that begins in the very early hours of the morning. Low rubber price now makes the farmers leave their plantation and switch to other crops. The average level of education of tappers in rubber plantation is elementary school. A similar scarcity exists for adept labor. Presently, the rubber processing and rubber product manufacturing industry both experience a shortage of qualified personnel in engineering and research and development.

Based on the 2019 GCI, Indonesia ranked 74th out of 141 countries in terms of "innovation capability". This is much lower than Malaysia and Thailand, respectively, ranking 30th and 50th. Indonesia's natural rubber production in total is five times larger than that of Malaysia and three times larger than Vietnam (Lidung and Jamil 2018). The Indonesian government is clearly aware of replanting rubber plantation with scheme 60:40 to increase productivity. The government was built infrastructure massively include information infrastructure. The government has also improved the rubber research institution for R\&D in Indonesia to provide superior clones to replanting policy and downstream industrial development to produce diversification to absorb natural rubber. 


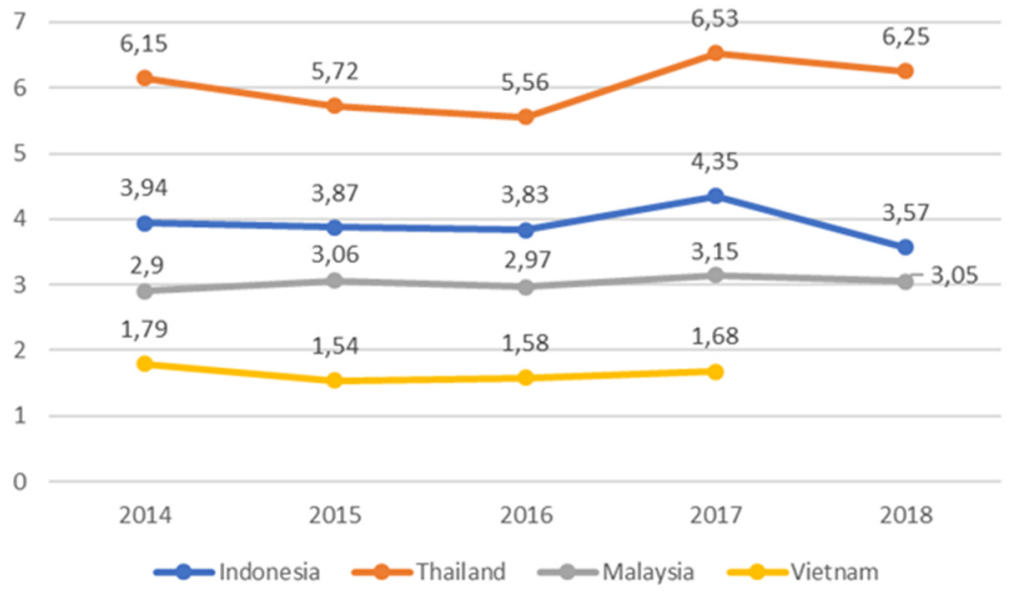

Figure 9. Comparative Competitiveness (RCA Value) of 4 Natural Rubber Producing Countries

According to the RCA value from 2014 to 2018, Indonesia's rubber competitiveness tends to decrease (in Figure 9). In 2017, it increased to 4.35, the highest value during that period. As a result, the lowest value was in 2018, when the RCA was 3.57 because the export value of Indonesian rubber in that year was the lowest. Indonesia ranks second in the RCA after Thailand.

According to Porter (1993), an abundance of natural resources and a large number of human resources give Indonesia an advantage in generating competitiveness in the international market. However, the low quality of its human resources has a negative impact on Indonesia's competitiveness. This abundant natural resource cannot ensure consistent productivity in Indonesian rubber because farmers are unable to organize resource and optimize their potential productivity.

In the global trade of rubber, Indonesia is an active producing country. From 2014 to 2018 , the RCA of Indonesian rubber was greater than one. During the same period, the comparative advantage of Indonesian rubber was generally favorable, with an average RCA value of 3.91. These findings were consistent with Daryanto's research (2010), which found that Indonesian rubber has a comparative edge in the global market.

\subsection{Demand Conditions}

Porter (1990) states that the size of the domestic market is possibly significant in particular industries with high investment costs on R\&D or considerable economies of scale. Currently, natural rubber demand in Indonesia accounts for only about $19 \%$ of aggregate production, whereas the remaining is exported. However, over the last few years, the number of natural rubber in national demand has been growing in the infra-structure industry, such as rubberized asphalt, rubber dam, bridge bearing pad, dock fender, rail pad, etc. A similar trend could contribute to strengthening Indonesia's rubber industry (in Figure 10).

The current largest consumer of Indonesian rubber in primary forms is the automotive tire market, dominated by large multinationals, such as Bridgestone, Michelin, and Goodyear. The primary raw materials used are TSR and RSS. Given that the auto industry remains expanding, car tires in demand will keep increasing as well. At the end of the 1980s, Bridgestone, Goodyear, and Michelin held 55\% of the global tire market. By 2009, these three leading tire companies' market share had dropped to around 44\%(DBS 2011). Increased competition from Chinese and Korean tire manufacturers may help strengthen the negotiating position of upstream rubber businesses.

Rubber footwear, retread tires, and rubber gloves producers place the second, third, and fourth largest rubber users in Indonesia, respectively. The primary raw material used in these three industries is concentrated latex. As the demand is growing in these sectors, fueled primarily by rising affluence in rising markets, the effort to boost productivity and innovation through investment in technology will be stimulated.

Companies may gain competitive advantages through their experienced and demanding domestic customers (Porter 1990). Because most of the rubber industry's customers come from industries, their demands are usually in line with internationally accepted standards. Therefore, product distinction and advanced demand are regarded insignificant in this context. 


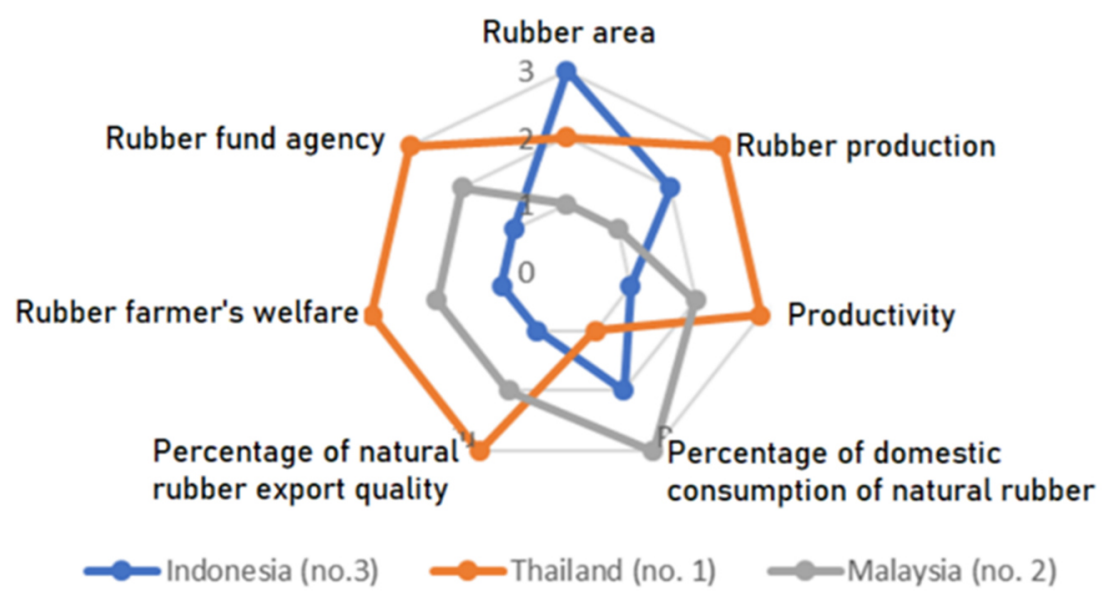

Figure 10. Performance of Competitiveness Factors of Rubber Industry in 3 ITRC Countries

The performance of competitiveness rubber from three ITRC countries reveals that Indonesia ranks third (in Figure 10). Indonesia has high performance in rubber plantation area and rubber production. The other factor like productivity, domestic rubber consumption, kind of rubber export quality, the prosperity of farmers, and rubber institution fund still low compare with Thailand and Malaysia.

\subsection{Related and Supporting Industries}

Supplier industries. The availability of low-cost inputs may support the competitiveness of domestic downstream industries. Rubber plantations are the primary raw material suppliers in the rubber industry. Smallholders own the majority of plantations (in Figure 11). Rubber plantations of Indonesia are the least fruitful in the world due to old plants, poor maintenance causes low rubber price and the outbreak of pestalotiopsis disease of rubber leaf. To address this, the government must continue to improve rubber variations and advanced farming methods.

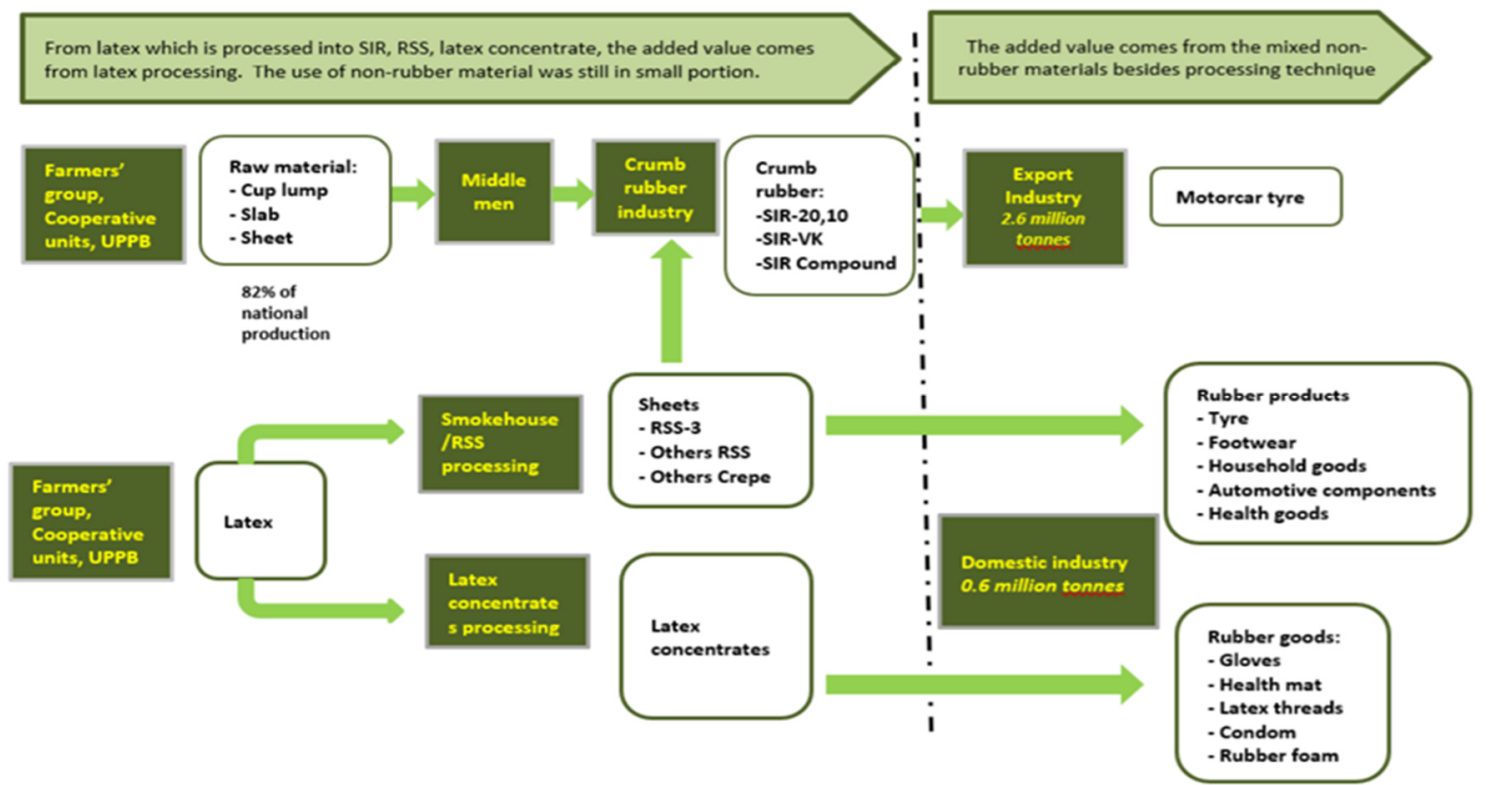

Figure 11. The Value Chain of Indonesia's Rubber Industry

Numerous upstream companies have deliberately decided on putting their manufacturing factories near plantations in order to obtain first access to raw materials and alleviate transportation costs. When related industries are located close together, the interaction and coordination between actors in the value chain become more effective (Marimin et al. 2014). The development of input production suppliers in the upstream sector is adequate. After reformed the institution of RPN (national plantation research), the superior clones for rubber replanting can provide easily.

According to interviews with rubber industry executives, reliable suppliers are critical for advancing competitiveness (in Figure 12). The latest increase in natural rubber rates has generated inducement for some unscrupulous farmers to attempt to degrade rubber in order to increase their profits. Trustworthy suppliers can assist businesses in controlling the product quality and lowering cleaning monitoring costs. 


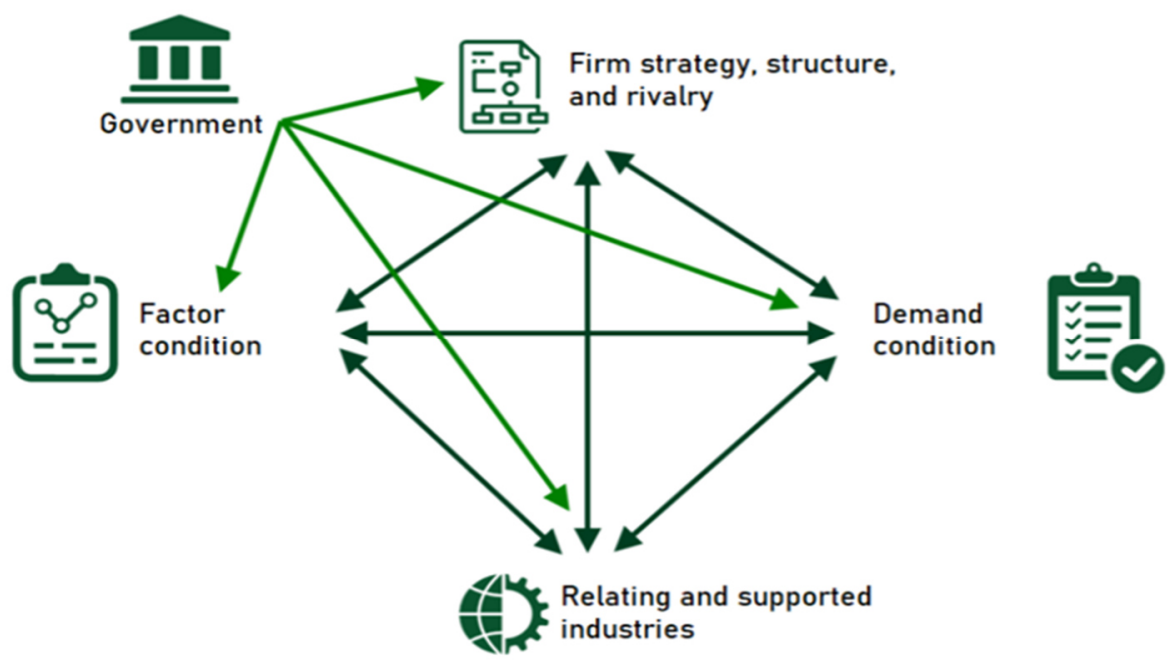

Figure 12. Analysis of The Competitiveness of The Rubber Industry According to The Porter Diamond Model

Related industries. At present, the automobile industry is the most important related industry for rubber. In terms of export value, Indonesia's automobile industry is expected to be the third-largest in the world- 10 billion US dollars in 2017 (BPS 2019). Many world-famous automakers, including Honda, Toyota, Suzuki, Hino, Mitsubishi, Nissan, Isuzu, and Daihatsu, have their manufacturing base in Indonesia. All of these companies obliquely encourage local upstream producers to adopt modern technologies and improve product quality.

Nonetheless, local firms' technological development in the downstream sector calls for significant improvement. For instance, car tire companies in Indonesia can only produce bias common radial tires, but not more sophisticated radial tires or tire for large and heavy vehicles. The rate of technology transfer to Indonesian partners is unsatisfactory in joint ventures. According to the 2019 Global Competitiveness Index, Indonesia ranks $74^{\text {th }}$ and $83^{\text {rd }}$ out of 141 countries in terms of "innovation capability" and "research and development". Thailand, Indonesia's main competitor, is ranked $50^{\text {th }}$ and $56^{\text {th }}$, respectively.

Domestic machinery suppliers also underserve Indonesia's rubber industry. Currently, all suppliers of manufacturing machinery and of molding and testing equipment rely on foreign technology.

\subsection{Firm Strategy, Structure, and Rivalry}

Generally, there are two sectors of the rubber industry, namely, upstream and downstream sectors. The figure provides some essential information about the outputs of various parts of the value chain.

Rubber companies found in the upstream and downstream sectors typically place their factories near raw material sources. Rubber clusters are possibly discovered in every component production center of Indonesia. The major clusters, however, are found in Sumatera and Kalimantan. Inside a cluster, information stream and technological exchange opportunities become more efficient, resulting in increased competitiveness.

The upstream sector. Rubber processing entails the production and marketing of main natural products. Since 2006, Indonesia has been the world leader in the rubber industry. The majority of the output is exported. Products that are not exported are then supplied to domestic industries, including the auto industry, retread tires industry, footwear industry, glove industry, and other manufacturing industries.

To date, there are 157 rubber processing factories across the country (Tempo 2014), most of which are largescale factories with their international sales and distribution network, as well as demonstrating vertical integration through business expansion into the rubber products industry (forward integration). In order to fully regulate the entire value chain, several companies also have rubber plantations (backward integration).

The downstream sector. The rubber products industry in Indonesia has a history that dates back to over 60 years. At that time, the goal of production was to increase agricultural commodity exports. Production was frequently done on a small scale by family businesses and without employing much technology. The abundance of raw materials and lower labor costs drew overseas rubber firms to enter Indonesia later on through direct investment or joint ventures with Indonesian companies. Tire manufacturers such as Bridgestone, Michelin, and Goodyear were early adopters in this regard. Safe Skin and Allegiance Health Care entered the market in response to the rising request for exploration gloves and condoms. These foreign firms have played an important role in the development of Indonesia's rubber industry.

The market structures for various rubber commodities are distinct (Purnomowati et al. 2015). Three overseas firms, including Goodyear, Michelin, and Bridgestone, predominate the vehicle tire sector, accounting for over $90 \%$ combined market share. In this sector, a few Indonesian companies participate. Their technology, however, lags far behind that of the major corporations. In terms of latex-based products, there are six registered rubber 
glove factories of varying sizes (IRGMA 2019). The large-scale manufacturers are joint ventures, whereas the mid-scale and small-scale factories are predominantly from Indonesia. There are 248 retread tire factories, the majority of which are small-scale, employing about 50 workers each.

\subsection{Government Policy Intervention}

The 2019 GCI ranks "policy instability" $38^{\text {th }}$ in "the most problematic factors for doing business (in Indonesia)." Albeit the plans initiated by the government in the "Rubber Policy" including improving the quality of natural rubber, increasing domestic rubber downstream, incorporating rubber commodities and rubber wood, promoting R\&D (Setiawan 2012), and initiatives for human resource development, only a small number of programs have had an apparent impact.

The government has conducted ITRC (International Tripartite Rubber Councils) rubber diplomacy at the international level. The three policies implemented are AETS (Agreement Export Tonnage Scheme), SMS (Supply Management Scheme), and DPS (Demand Promotion Scheme). The three countries agreed to export cutbacks of 240,000 metric tons of NR. SMS policy is carried out through replanting plantations and mixed farming. DPS policy is carried out through increasing domestic rubber downstream.

The government also intends to collect an export tax known as "cess" to fund smallholder rubber tree replanting. The Rubber Replanting Fund Act allows for the collection of "cess" from exporters at a rate of approximately Rp 100 per kilogram, de-pendent on the global rubber price (if international rubber price is more than 1.4 US\$ per kilogram). Rubber replanting targets by 2027 are 700,000 ha. Farmers will be subsidized at the rate of Rp 22.6 million per ha for the rubber trees replanting aged 25 years or older. The subsidy is disseminated over five years to cover numerous planting costs. The sum total of "cess" that will be collected is estimated to be around USD 18.3 million. The allocation portion of the "cess" fund is no more than $5 \%$ of the "cess" collected to subsidize rubber research. The lion's share of $85 \%$ is set aside for farmers' replanting costs, whereas the remaining ten percent going toward administrative costs.

The Rubber Replanting Aid Fund has assisted smallholders in making the switch to higher-quality varieties of rubber trees. The fund has also encouraged farmers to endorse more sophisticated cultivation techniques as well as better quality fertilizers and chemicals, allowing for denser plots and higher gains. Thailand and Malaysia both have a similar rubber "cess" system.

FTAs are generally regarded favorably by exporters. These developments are expected to increase the number of rubber exports. Given that FTAs include tax breaks for other products containing rubber parts, similar agreements can indirectly raise rubber industry revenues.

Sustainable policies rubber in Indonesia can be divided into four subsystems, that are downstream subsystem, upstream subsystem, marketing subsystem, and supporting subsystem. In the downstream subsystem, there is a policy using natural rubber for infrastructure (Nidhiprabha 2019). In the upstream subsystem, there is a rubber replanting policy integrated with mixed farming to increase the productivity and prosperity of farmers (Otten et al. 2020). There is a policy to revitalise the UPPB (farmer's processing and marketing unit) role in the marketing subsystem. In supporting subsystem, there is initiate to develop The Institution for Rubber Funding for smallholder. Overall, all countries member of ANRPC (Association of Natural Rubber Producing Countries) should work together to build a remunerative price system (Verico 2019; Soontaranurak and Dawson 2015), not only depend on the commodity exchange, which mostly influences by the customer/buyer (in Figure 13).
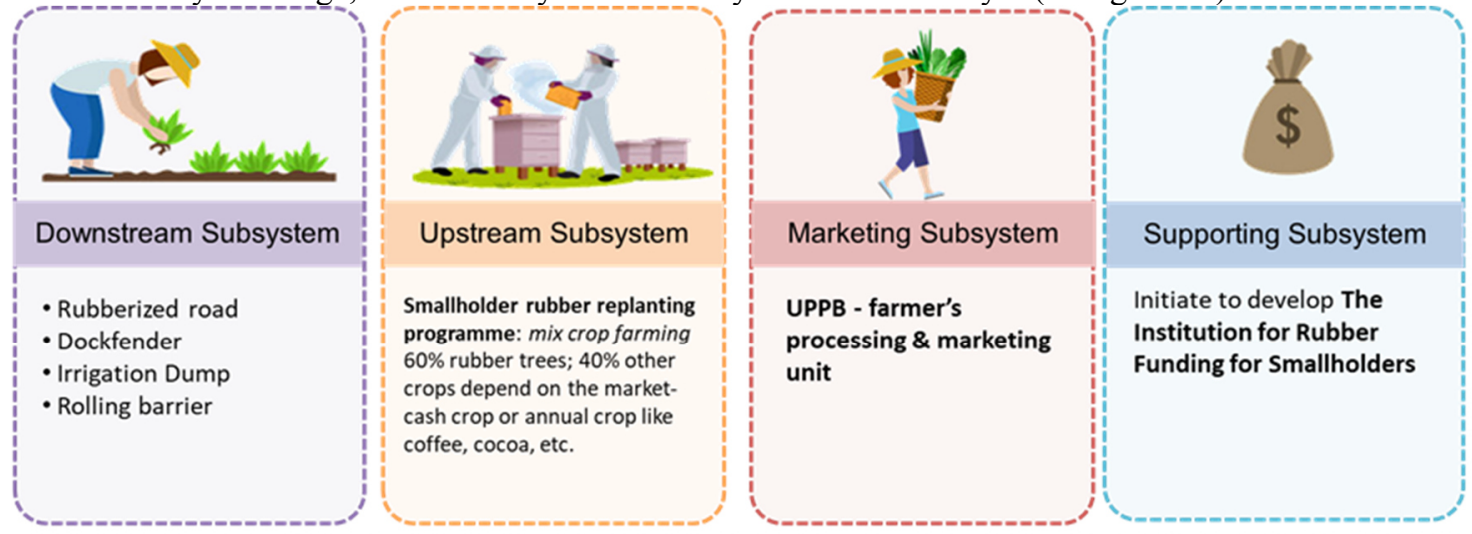

We need work together to build remunerative price system, not only depend on the commodity exchange $\rightarrow$ which mostly influence by the consumer/buyer

Figure 13. Sustainability Policies Rubber in Agribusiness Perspective Based Value Chain in Indonesia (Gapkindo, 2019; Yanita et al. 2016) 


\section{Conclusion}

Indonesia's natural rubber competitiveness compared to other countries can be viewed from 4 aspects, namely the area of rubber, rubber production, rubber productivity, and RCA value. Other aspects that need to be considered related to competitiveness include the utility of crumb rubber factories, the composition of domestic use, the type of quality of natural rubber produced, the composition of processed natural rubber exports, and the welfare of farmers. This section is not mandatory but can be added to the manuscript if the discussion is unusually long or complex.

Indonesia's rubber RCA value is ranked second and has been declining since 2017. Thailand has the highest rubber RCA value of 4 other producing countries and experienced an upward trend in the 2014-2018 period. Malaysia has an RCA value at position no. 3 and tend to be stable. Vietnam has an RCA value that has been on an upward trend since 2015-2017. This is due to the price of rubber, which tends to fall below the eco-nomic value of production, causing many farmers in Indonesia to switch to other crops, especially oil palm. In addition, the institutional management and support of the Thai government for rubber commodities can make its competitiveness well maintained. Although on the other hand, Thailand is at least compliant with the export restriction agreements of 3 rubber producing countries (ITRC). Vietnam as a new rubber player that has not yet joined the ITRC is not bound by export restriction regulations and has new plants that produce high productivity. The strategy to improve rubber competitiveness can be carried out through three ways, such as the upstream sector (increasing productivity), downstream industry, and funding policy. The increasing productivity is conducted by implementing programs of rubber replanting, integrated farming, and managed tapping systems. Managed tapping system is carried out by applying low tapping frequency and improving tapper skills. Downstream industry is carried out by creating rubberized road, rubber tread (vulcanization), and infrastructure. The funding policy is implemented through the establishment of rubber CESS or Indonesian Estate Crop Fund Agency.

\section{References}

Aiginger, K. (2013). Competitiveness under new perspectives. EU.

Besanko, D. et al. (2010). Economics of strategy. Hoboken: John Wiley \& Sons.

Booranapin, N. (2000). A study of comparative advantage and factors affecting thailand's rubber exports to Japan. Thesis Dissertation. University of the Thai Chamber of Commerce.

Central Bureau of Statistics Republic of Indonesia [BPS]. (2013). Agricultural census. Jakarta: Statistic of bureau.

Central Bureau of Statistics Republic of Indonesia [BPS]. (2018). Statistic Indonesia export. Jakarta: Statistic of bureau.

Central Bureau of Statistics Republic of Indonesia [BPS]. (2019). Labor forced situation in Indonesia February 2019. Jakarta: Statistic of bureau.

Daryanto, A. (2010). Posisi daya saing pertanian indonesia dan upaya peningkatannya. Bogor: IPB University. DBS Vickers Research. (2011). Rubber value chain. Regional Industry Focus.

International Rubber Study Group [IRSG]. (2019). A sustainable growth path for global rubber economy. Singapore: World Rubber Summit.

Indonesian Rubber Glove Manufacturer Association [IRGMA]. (2019). Industri sarung tangan latex Indonesia. Jakarta: IRGMA.

Ita, P.A., \& Gross, A.C. (1995). Industry corner: world rubber and tire - industry overview. Business Economics, $30,1,58-63$.

Ketels, C. (2016). Review of competitiveness frameworks. Dublin: National Competitiveness Council.

Lidung, \& Jamil, A.S. (2018). Competitiveness and market consentration position of Indonesia's natural rubber export in global market. Agrisep 17, 2, 119-128.

Marimin, D.M.A., Machfud, Putra, I.F.M.P., \& Wiguna, B. (2014). Value chain analysis for green productivity improvement in the natural rubber supply chain: a case study. Journal of Cleaner Production. 85, 201-211.

Min, S., Wang, X., Liu, M., \& Huang, J. (2018). The asymmetric response of farmers to an expected change in the price of rubber: the roles of sunk costs and path dependency. Land Use Policy. doi: 10.1016/ j.landusepol.2018.09.006.

Moon, H.C., Rugman, A.M., \& Verbeke, A. (1995). The generalized double diamond approach to international competitiveness. In: Rugman, A., Van Den Broeck, J., \& Verbeke, A., (eds). Research in global strategic management. Greenwich: Emerald Group Publishing.

Nidhiprabha, B. (2019). Commodity price cycles, the agricultural trap, and Thailand's incessant subsidies. Asian Economic Papers. doi: 10.1162/asep_a_00692.

Organization for Economic Cooperation and Development [OECD]. (2001). Glossary of statistical terms. [Online] Available: http://stats.oecd.org/glossary/detail.asp?ID1/4399 (Oct 20, 2019).

Otten, F., Hein, J., Bondy, H., Faust, H. (2020). Deconstructing sustainable rubber production: contesting narratives in rural Sumatra. Journal of Land Use Science. doi: 10.1080/1747 423X.2019.1709225.

Porter, M.E. (1990). The competitive advantage of nations. New York: The Free Press. 
Porter, M.E. (1993). Keunggulan bersaing menciptakan dan mempertahankan. Jakarta: Erlangga.

Purnomowati, H.D., Dwidjono, H.D., Widodo, S., Hartono, S. (2015). Market integration analysis of Indonesian natural rubber in the world market. International Journal of Agriculture. 3, 1, 15-27.

Rubber Association of Indonesia [Gapkindo]. (2019). Statistic year book 2018. Jakarta: Gapkindo.

Setiawan, H. (2012). Technology innovation roadmap to industrial development of rubber-raw material in South Sumatera (ergonomics SHIP approach \& appropriate technology point of view). Procedia Economics and Finance. 4, 255-263.

Sinar Tani. (2019). Biar produktif, peremajaan karet ditargetkan 50 ribu hektar/tahun. [Online] Available:https://tabloidsinartani.com/detail/indeks/kebun/8155-Biar-Produktif-Peremajaan-Karet Ditargetkan-50-Ribu-hektartahun (Oct 20, 2019).

Soontaranurak, K., Dawson, P.J. (2015). Rubber acreage supply response in Thailand: a cointegration approach. The Journal of Developing Areas. 49, 2, 23-38.

Tambunan, T. (2001). Industrialisasi di negara sedang berkembang: kasus Indonesia. Jakarta: Ghalia Indonesia.

Tempo. (2014). Industri otomotif jadi tumpuan ekspor. [Online] Available: https://www.gooto.com/read/612988/industri-otomotif-jadi-tumpuan-ekspor (Oct 20, 2019).

Verico, K. (2013). Economic cooperation in natural rubber: the impacts on natural rubber's world supply and Indonesia's economy. Asian Journal of Agriculture and Development. doi: 10.22004/ag.econ.199419.

World Economic Forum [WEF]. (2019). The global competitiveness report 2019. Switzerland: WEF.

Yanita, M. et al. (2016). Determinant analysis for rubber export in Indonesia. International Journal of Scientific and Research Publications. 6,9, 478-481. 